\title{
Article \\ The Effects of Suaeda salsa/Zea mays L. Intercropping on Plant Growth and Soil Chemical Characteristics in Saline Soil
}

\author{
Shoule Wang ${ }^{1,2}$, Zhenyong Zhao ${ }^{1}$, Shaoqing Ge ${ }^{1,2}$, Ke Zhang ${ }^{1}$, Changyan Tian ${ }^{1, *}$ and Wenxuan Mai ${ }^{1}$ \\ 1 State Key Laboratory of Desert and Oasis Ecology, Xinjiang Institute of Ecology and Geography, \\ Chinese Academy of Sciences, Urumqi 830011, China; wangshoule17@mails.ucas.ac.cn (S.W.); \\ zhaozhy@ms.xjb.ac.cn (Z.Z.); geshaoqing18@mails.ucas.ac.cn (S.G.); zhangke@ms.xjb.ac.cn (K.Z.); \\ maiwx@ms.xjb.ac.cn (W.M.) \\ 2 University of Chinese Academy of Sciences, Beijing 100049, China \\ * Correspondence: tianchy@ms.xjb.ac.cn
}

check for updates

Citation: Wang, S.; Zhao, Z.; Ge, S.; Zhang, K.; Tian, C.; Mai, W. The Effects of Suaeda salsa/Zea mays L. Intercropping on Plant Growth and Soil Chemical Characteristics in Saline Soil. Agriculture 2022, 12, 107. https: / /doi.org/10.3390/

agriculture12010107

Academic Editor: Ana P G C Marques

Received: 24 November 2021

Accepted: 11 January 2022

Published: 13 January 2022

Publisher's Note: MDPI stays neutral with regard to jurisdictional claims in published maps and institutional affiliations.

Copyright: (c) 2022 by the authors. Licensee MDPI, Basel, Switzerland. This article is an open access article distributed under the terms and conditions of the Creative Commons Attribution (CC BY) license (https:// creativecommons.org/licenses/by/ $4.0 /)$.

\begin{abstract}
Halophytes possess the capacity to uptake high levels of salt through physiological processes and their root architecture. Here, we investigated whether halophyte/non-halophyte intercropping in saline soil benefits plant growth and contains root-dialogue between interspecific species. Field and pot experiments were conducted to determine the plant biomasses and salt and nutrient distributions in three suaeda (Suaeda salsa)/maize (Zea mays L.) intercropping systems, set up by non-barrier, nylon-barrier, and plastic-barrier between plant roots. The suaeda/maize intercropping obviously transferred more $\mathrm{Na}^{+}$to the suaeda root zone and decreased salt and $\mathrm{Na}^{+}$contents. However, the biomass of the non-barrier-treated maize was significantly lower than that of the nylon and plastic barrier-treated maize. There was lower available $\mathrm{N}$ content in the soil of the non-barrier treated groups compared with the plastic barrier-treated groups. In addition, the $\mathrm{pH}$ was lower, and the available nutrient content was higher in the nylon barrier, which suggested that rhizospheric processes might occur between the two species. Therefore, we concluded that the suaeda/maize intercropping would be beneficial to the salt removal, but it caused an adverse effect for maize growth due to interspecific competition, and also revealed potential rhizospheric effects through the role of roots. This study provides an effective way for the improvement of saline land.
\end{abstract}

Keywords: maize; intercropping; Suaeda salsa; saline soil

\section{Introduction}

Salt stress is an abiotic factor that limits crop productivity and agricultural development worldwide. How to improve soil quality and the viability of non-halophytes (crops) in saline land is always an important issue. Previous studies showed that halophyte is a plant that can complete its entire life cycle on a high-salt soil owing to a series of adaptive strategies in its coordinated evolution with the environment [1-3]. Halophytes develop special mechanisms to resist and alleviate salinity stress over evolutionary time: (i) cells produce some osmotic substances to reduce water potential, and would favor the uptake of water from the outside; and (ii) halophytes can absorb $\mathrm{Na}^{+}$and compartmentalize it into vacuoles by an $\mathrm{Na}^{+} / \mathrm{H}^{+}$antiporter [4-6]. They can survive in media containing more than $200 \mathrm{mM} \mathrm{NaCl}$ and direct root damage in the surficial soil [7-9]. Wang et al. (2021) found that the decrement in salt content has occurred after halophytes were initially cultivated in virgin saline soil [10]. Etesami and Beattie (2018) reported that halophyte salinity-tolerant microorganisms improve non-halophyte adaptability to saline soils [11]. Shultana et al. (2020) also determined that the salt-tolerant PGPR (Bacillus tequilensis and Bacillus aryabhattai strains) produces a positive role on photosynthesis and stomatal conductance to increase the rice yield [12]. This gives us an idea that the efficient use of halophytes helps decrease the salt concentrations of saline soils, which might optimize the soil conditions for non-halophytes by intercropping system. 
Generally, intercropping or crop rotations has greatly induced plant growth, and the interspecific interactions give some crops nutrient competitive advantages and significantly superior yield levels [13-16]. The intercropping of water spinach and corn not only significantly weakens the toxic action of nitrate in the former plant, and it also reduces the nitrate accumulation in the soil [17]. These intercropping patterns usually involve rhizospheric dialogues, in which root exudates play important roles in delivering soil nutrients $[18,19]$. Sufficient transformational levels of nitrogen $(\mathrm{N})$, phosphorus $(\mathrm{P})$, and potassium $(\mathrm{K})$ are necessary to drive vegetative growth that promotes further nutrient acquisition in a plantroot system [20,21]. Non-halophytes might increase the soil nutrient availability by root exudates, which is good for halophyte requirements in intercropping systems. Liang and Shi (2021) also discovered an intercropping system involving cotton and halophytes, which significantly influenced salt removal, and accelerated crop productivity in saline soil [22]. Under the salt stress, halophytes are subject to the base ions $\left(\mathrm{Na}^{+}\right.$and $\left.\mathrm{Cl}^{-}\right)$, leading to osmotic stress. Thus, roots may produce excretions in response to the environment, which effectively are associated with soil salt, microbes, and nutrients $[19,23]$. Root excretions are necessary for altering and adapting to salt conditions to enhance the availability of soil nutrients and microbial activities [24,25], which affects root metabolism and development of non-halophytes. However, it is difficult to extrapolate the promotive effects on nonhalophytes in intercropping systems that contain distinct species. In intercropping systems, whether or not halophytes can reduce the salt content of saline soil through salt absorption to reduce the salt stress of non-halophytes, is an issue that should be further investigated.

Suaeda salsa, an annual halophyte, could complete body development in saline soil, and is able to assimilate $\mathrm{Na}^{+}$, which is considered an ideal halophyte for improving saline soil [23,26]. Maize always has an important influence on nutrients through rhizospheric activities in intercropping systems. How do the soil properties and the growth of two species vary in the suaeda and maize intercropping? We hypothesized that the suaeda and maize intercropping would decrease the soil salt content on the maize side, and increase nutrient movements through root interactions. In this study, three treatments (non-barrier, nylon-barrier, and plastic-barrier) between intercropping plant roots were adopted as per previous studies [14,27]. The objectives were as follows: (a) to analyze the effect of the suaeda/maize intercropping on biomasses; (b) to investigate the variations in $\mathrm{pH}$ and salt between the two root systems; and (c) to assess the interspecific competition or cooperation for nutrients (available $\mathrm{N}$ and $\mathrm{P}$ ) in the suaeda and maize intercropping system.

\section{Materials and Methods}

\subsection{Field Experiment}

The study was conducted at the Salt Farm Botanical Garden in Karamay $\left(45^{\circ} 28^{\prime} 6.38^{\prime \prime} \mathrm{N}\right.$, $84^{\circ} 59^{\prime} 41.61^{\prime \prime}$ E), Xinjiang Province, China. The study area is characterized by cold, windy winters and hot, dry summers. The annual mean temperature and precipitation are $8.1^{\circ} \mathrm{C}$ and $108.9 \mathrm{~mm}$ (Figure 1), respectively, and the light and heat are sufficient in this region, with $2734 \mathrm{~h}$ of sunshine, 200 frost-free $\mathrm{d}$, and effective and accumulated temperatures of up to $3968.1^{\circ} \mathrm{C}$. The soil chemical and physical properties in this experiment were measured, as indicated in Table 1. 


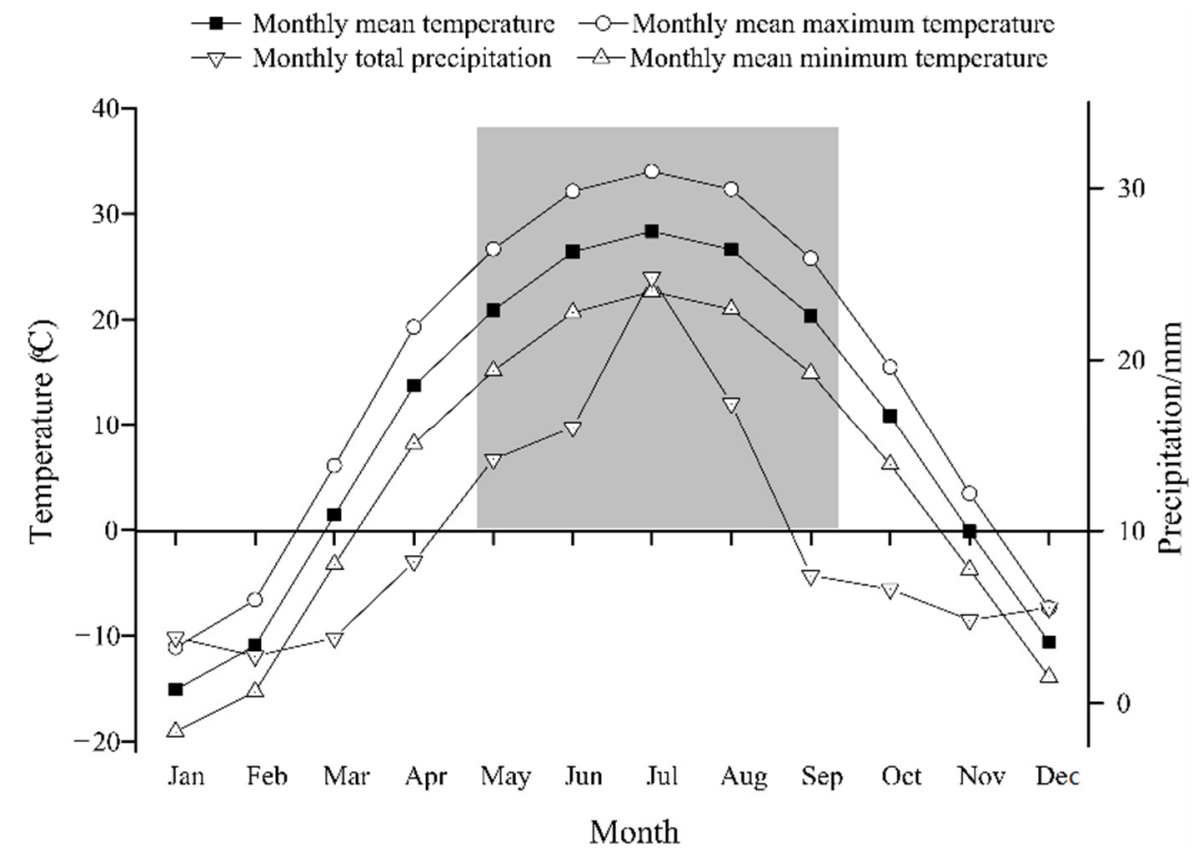

Figure 1. Monthly total precipitation, mean temperature, and maximum and minimum temperatures in the study area from NOAA's National Centers for Environmental Information (NCEI). The shadow represents the main growing season of halophyte from May to Sep.

Table 1. The field soil's chemical and physical properties.

\begin{tabular}{|c|c|c|c|c|c|c|}
\hline $\begin{array}{l}\text { Soil Depth } \\
\text { (cm) }\end{array}$ & $\mathrm{pH}$ & $\begin{array}{c}E C \\
\left(\mathrm{dS} \mathrm{m}^{-1}\right)\end{array}$ & $\begin{array}{c}\text { Total Salt } \\
\left(\mathrm{g} \mathrm{kg}^{-1}\right)\end{array}$ & $\begin{array}{c}\text { Available N } \\
\left(\mathrm{mg} \mathrm{kg}^{-1}\right)\end{array}$ & $\begin{array}{c}\text { Olsen-P } \\
\left(\mathrm{mg} \mathrm{kg}^{-1}\right)\end{array}$ & $\begin{array}{c}\text { Available K } \\
\left(\mathrm{mg} \mathrm{kg}^{-1}\right)\end{array}$ \\
\hline $0-10$ & 7.247 & 1.260 & 1.308 & 7.556 & 5.282 & 2.858 \\
\hline 10-20 & 7.403 & 1.027 & 2.567 & 13.208 & 5.369 & 3.099 \\
\hline $20-30$ & 7.383 & 0.616 & 1.833 & 7.032 & 4.876 & 2.336 \\
\hline $30-50$ & 7.373 & 0.691 & 2.025 & 6.308 & 4.110 & 2.448 \\
\hline 50-100 & 7.490 & 0.582 & 1.570 & 4.964 & 4.683 & 2.691 \\
\hline
\end{tabular}

Field experimental methods were used to analyze the effects of halophyte (suaeda) and non-halophyte (maize) intercropping systems on plant growth and soil chemical characteristics. Additionally, the root systems of the two species were separated by placing different materials between them, as follows: (1) the control, not separated (non-barrier treatment): the root systems of the different plants coexisted, allowing direct competitive and promotive effects; (2) roots separated by a $30 \mu \mathrm{m}$ nylon mesh (nylon-barrier treatment): the transmission of soil nutrients and microbial products could proceed belowground; and (3) roots separated by a plastic film (plastic-barrier treatment): there was no interaction between the roots of the two species. These conditions would expose the regulatory mechanisms behind the interactions at the root-soil interface of halophytes and non-halophytes.

The experiment had a split-plot design, with nine plots, and three replicates. The area of each individual plot was $6 \mathrm{~m} \times 5.6 \mathrm{~m}$. To satisfy nutrient requirements, the site was treated with urea of $590 \mathrm{~kg} \mathrm{ha}^{-1}(\mathrm{~N} \geq 46 \%)$, potassium sulfate of $163 \mathrm{~kg} \cdot \mathrm{ha}^{-1}\left(\mathrm{~K}_{2} \mathrm{O} \geq 50 \%\right)$ and superphosphate of $150 \mathrm{~kg} \mathrm{ha}^{-1}\left(\mathrm{P}_{2} \mathrm{O}_{5} \geq 14 \%\right)$. The nylon and plastic barriers were placed in the soil at $1 \mathrm{~m}$ depths, and the inter-row distance was $40 \mathrm{~cm}$.

The suaeda seeds were gathered in October 2018 from a botanical garden in Karamay, Xinjiang Province, China. The maize seeds (Cultivars: Silage Tieyan 53) were gather from Hejiayuan Agricultural Science and Technology Co. LTD, Beijing, China. Suaeda was sown in May 2019, and maize was sown 15 d later. Each intercropped plot included four rows of suaeda and three rows of maize. All rows of plant were irrigated with each drip line, 
and the interval of drip line and the inter-species distance were $40 \mathrm{~cm}$. The harvesting and gathering of root and soil samples were completed in August 2019. During the growth period, the plots were manually irrigated and weeded regularly with fresh water of $8 \mathrm{~m}^{3}$, where the discharge rate of emitters was $2 \mathrm{~L} \mathrm{~h}^{-1}$.

The shoot biomasses of the two species were determined by harvesting from the intercropping systems after $60 \mathrm{~d}$ of growth. To clearly determine the root spatial distributions and correlations with soil properties, the soil was stratified in the vertical direction to acquire the roots. At each plot, two $30 \times 30 \times 50 \mathrm{~cm}$ soil samples were excavated for suaeda and for maize in the adjacent row. The samples were stratified every $5 \mathrm{~cm}$ and then divided into 10 parts. The roots were obtained from the soil samples and washed free of soil. All the samples were over dried by treating at $105^{\circ} \mathrm{C}$ for $30 \mathrm{~min}$ and then dried at $65^{\circ} \mathrm{C}$ for $48 \mathrm{~h}$.

The potential deliveries of soil substances were investigated between the two species by horizontal soil stratification. The junction between the two root systems was determined to occur at a $10 \mathrm{~cm}$ depth in the middle of the plants. The $5 \mathrm{~cm}$ topsoil layer was initially removed and then the soil was divided into ten $1 \mathrm{~cm}$ thick layers (Figure 2).

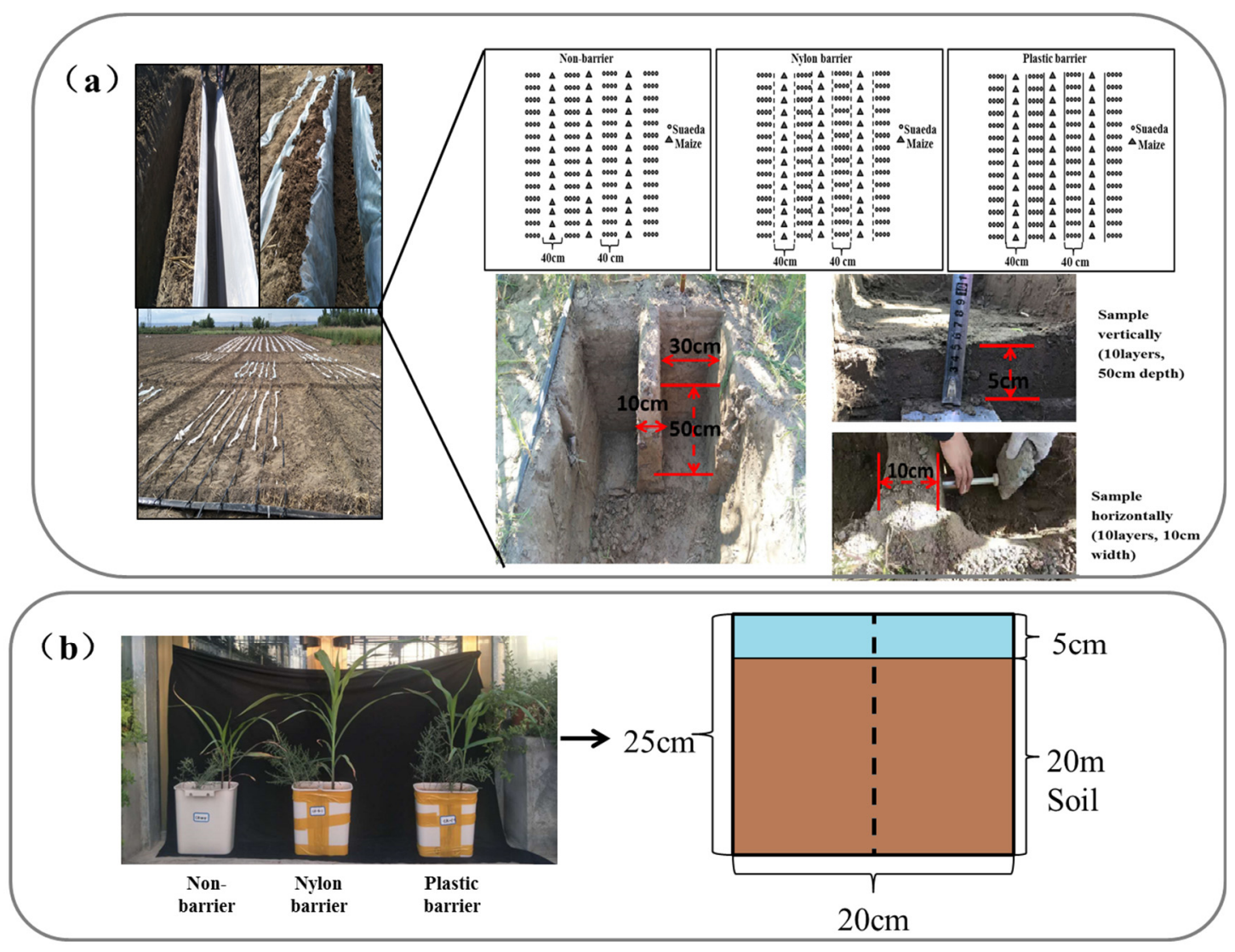

Figure 2. Soil samples from the suaeda/maize intercropping systems: (a) In the field experiment, soil samples were collected horizontally at $5 \mathrm{~cm}$ depths and vertically at $1 \mathrm{~cm}$ depths. (b) The pot experiment was conducted in concert with the field experiment.

The soil $\mathrm{pH}$ was measured using a $\mathrm{pH}$ meter. The soil conductivity (EC) and slat content were measured using a conductivity meter and residue drying quality method (10 g soil in $50 \mathrm{~mL}$ water), and diluted extracts were analyzed for $\mathrm{Na}^{+}$(Flame Photometer, 735 ICP-OES). The available $\mathrm{N}$ was measured using the alkali hydrolysis diffusion method ( $5 \mathrm{~g}$ soil in $50 \mathrm{~mL}$ solution). The available $\mathrm{P}$ (Olsen-P) was measured using the molybdenum antimony anti-colorimetric method ( $2.5 \mathrm{~g}$ soil in $50 \mathrm{~mL}$ solution) [28]. 


\subsection{Pot Experiment}

A pot experiment was conducted in 2019 to verify the field results. Saline soil was collected from the experimental station at Changji, Xinjiang Province, China $\left(44^{\circ} 09^{\prime} 59^{\prime \prime} \mathrm{N}\right.$, $\left.87^{\circ} 04^{\prime} 56^{\prime \prime} \mathrm{E}\right)$. Then, the soil was air-dried and passed through a $2 \mathrm{~mm}$ sieve. The soil

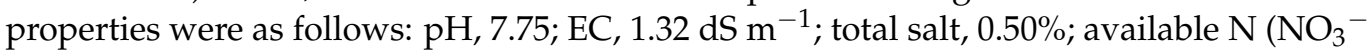
and $\mathrm{NH}_{4}{ }^{+}$), $33.68 \mathrm{mg} \mathrm{kg}^{-1}$; Olsen-P, $4.62 \mathrm{mg} \mathrm{kg}^{-1}$; and available $\mathrm{K}, 0.25 \mathrm{~g} \mathrm{~kg}^{-1}$.

To identify variations in plant growth in the suaeda and maize intercropping, the pot experiment was established using three inter-species root treatments. The intercropping system's equipment was shown in Figure 2b. The pot tube had an inner length of $20 \mathrm{~cm}$, width of $10 \mathrm{~cm}$, and height of $25 \mathrm{~cm}$. The cultivars of maize and suaeda seeds were consistent with those in the field experiment.

To ensure an adequate nutrient supply for plant growth, the soil was fertilized with $0.20 \mathrm{~g} \mathrm{~kg}^{-1}$ of $\mathrm{N}$ and $0.15 \mathrm{~g} \mathrm{~kg}^{-1}$ of $\mathrm{P}_{2} \mathrm{O}_{5}$ [29]. The pot was filled with $8.0 \mathrm{~kg}$ of airdried soil, which was divided using a nylon or plastic barrier in the middle position. We always established three treatments (non-barrier, nylon-barrier, and plastic-barrier) and four replicates for each treatment. Then, two liters of water was added, and the soil was allowed to stand for $5 \mathrm{~d}$. In July 2019, on one side per pot, 20 suaeda seeds were sown and grown to $4 \mathrm{~cm}$ before thinning. After $15 \mathrm{~d}$, on the other side of each pot, four maize seeds were sown. The weighing method was used to supply water to field capacity $(20 \%, w / w)$ to reduce the influence of water on plant growth.

The aboveground parts of suaeda and maize were harvested at approximate $45 \mathrm{~d}$ after sowing. All the samples were treated at $105^{\circ} \mathrm{C}$ for $30 \mathrm{~min}$ and then dried at $65^{\circ} \mathrm{C}$ for $48 \mathrm{~h}$, and the rhizosphere soil of suaeda and maize were collected by shaking off the soil adhering to the root surface $(0-3 \mathrm{~mm})$ [30]. Then, the determination methods of soil chemical characteristics were consistent with that in the field experiment.

\subsection{Statistical Analyses}

An analysis of variance was used to determine the differences in the shoot, soil salt, and nutrient contents among the three treatments with SPSS statistical software (version 19.0, IBM SPSS Inc, Chicago, IL, USA) and R software (version 4.0.3-win, R Foundation for Statistical Computing, Vienna, Austria). Significant differences among means were separated using least-significant difference (LSD) at the $p<0.05$ probability level. Using the smooth fit method, we also detected spatial variations in the soil $\mathrm{pH}$, salt content, and nutrients of the two species.

\section{Results}

\subsection{Plant Biomasses}

The suaeda/maize shoot biomasses and $\mathrm{N}$ absorptions were determined in the three intercropping systems (Figure 3). The maize biomass in the non-barrier treatment was 11.2\% and $17.1 \%$ lower than that in the plastic-barrier and nylon-barrier treatment, respectively (Figure 3a). The plant development observed in the pot experiment was different to that observed in the field experiment. There was not a significant difference in the suaeda biomasses, but the maize biomass in the non-barrier treatment was significantly lower $3.2 \mathrm{~g}$ per plant than in the plastic-barrier treatment (Figure 3b). 

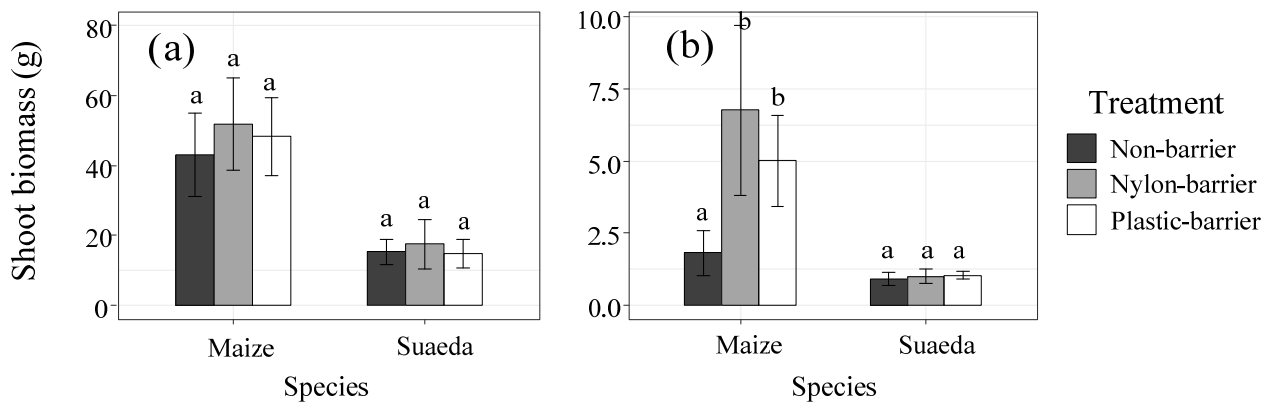

Figure 3. The shoot biomasses of maize and suaeda in the different treatments: (a) Field experiments; (b) Pot experiments. Lower case letters on the column indicate the significant differences among three treatments.

\subsection{Soil EC, Salt, and $\mathrm{Na}^{+}$Contents}

The salt contents in the different suaeda-associated soil layers in the non-barrier treatment were lower than those in the nylon- and plastic-barrier treatments, as measured in the 5-15 cm and 20-50 cm soil layers (Figure $4 \mathrm{~A}(\mathrm{a}-\mathrm{c})$ ). Compared with the plasticbarrier treatment, the nylon-barrier treatment resulted in a higher soil salt concentration on the suaeda side than on the maize side (Figure $4 \mathrm{~A}(\mathrm{~b})$ ), and the EC and $\mathrm{Na}^{+}$values were significantly higher (exceeded $0.345 \mathrm{dS} \mathrm{m}^{-1}, 0.032 \mathrm{~g} \mathrm{~kg}^{-1}$ ) in the pot experiments (Figure $4 \mathrm{~B}(\mathrm{a})$ ). The $\mathrm{Na}^{+}$concentration displayed lower in the non-barrier treatment than that in the plastic-barrier (Figure $4 \mathrm{~B}(\mathrm{~b})$ ).
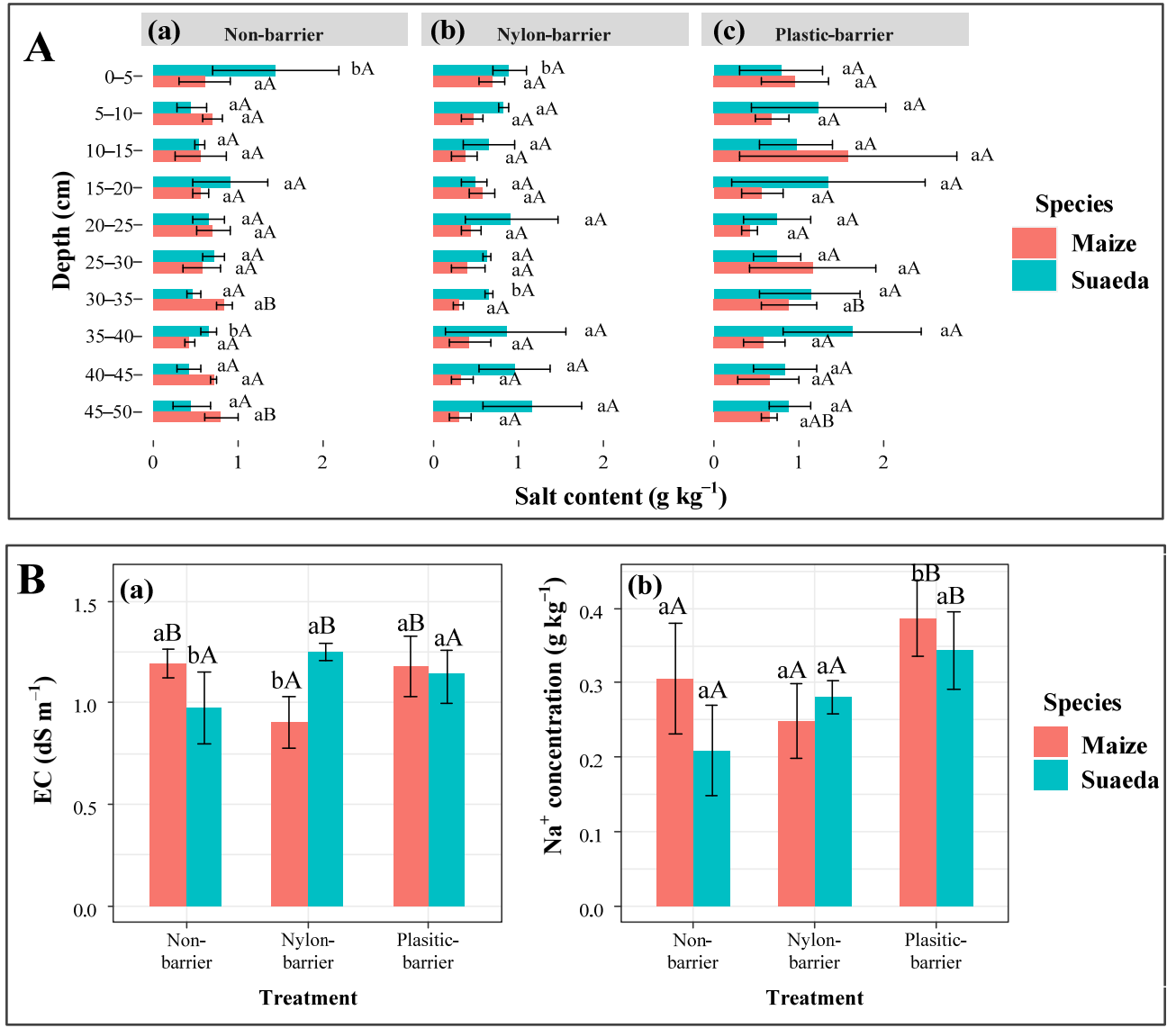

Figure 4. The soil salt, EC, and $\mathrm{Na}^{+}$in the different treatments: $(\mathbf{A}(\mathbf{a}-\mathbf{c}))$ Salt content in non-, nylon-, and plastic-barrier treatment of field experiment; $(\mathbf{B}(\mathbf{a}, \mathbf{b})) \mathrm{EC}, \mathrm{Na}^{+}$content of pot experiment. Capital letters on the column indicate the significant difference differences among three treatments. Lower case letters on the column indicate significant differences between two species. 


\subsection{Soil Available $N$ and Olsen-P Contents}

Differences in the available $\mathrm{N}$ and Olsen-P contents in the three intercropping systems existed to a certain extent (Figure 5). The soil available $\mathrm{N}$ content in the non-barrier treatment was also $0.0104 \mathrm{~g} \mathrm{~kg}^{-1}$ lower than in the plastic-barrier treatment (Figure $5 \mathrm{~A}(\mathrm{~b}, \mathrm{c})$ ). The similar results were found in pot experiment as showed in Figure $5 \mathrm{~B}(\mathrm{a})$. The Olsen-P content in the plastic-barrier treatment was lower than in the non-barrier and nylon-barrier treatments though there was not significant (Figure $5 \mathrm{~A}(\mathrm{~d}-\mathrm{f})$ ).
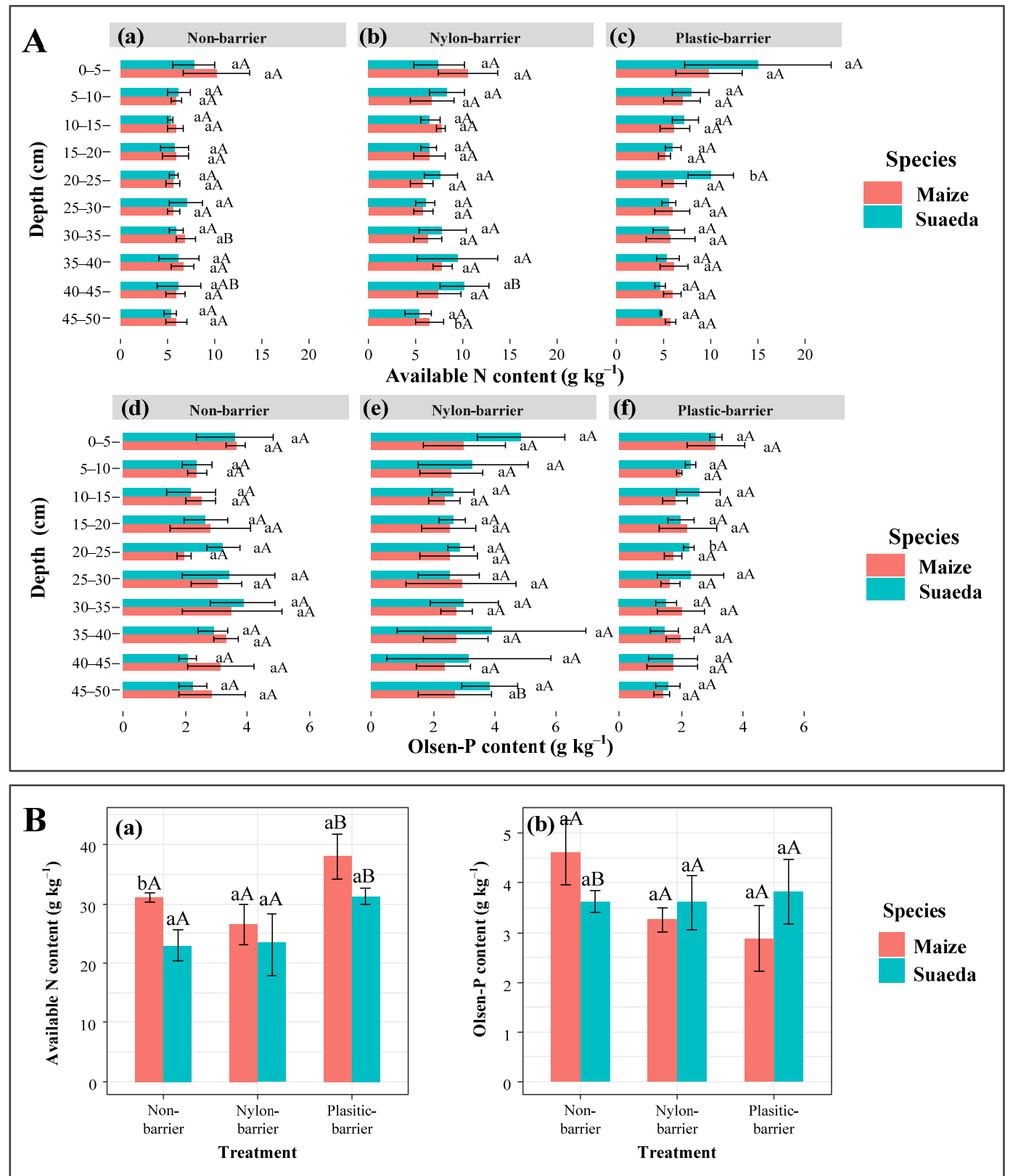

Figure 5. The available $\mathrm{N}$ and Olsen-P contents in the different treatments: $(\mathbf{A}(\mathbf{a}-\mathbf{c}))$ Available $\mathrm{N}$ contents in non-, nylon-, and plastic-barrier treatment of field experiment; $(\mathbf{A}(\mathbf{d}-\mathbf{f}))$ Olsen-P contents in non-, nylon-, and plastic-barrier treatment of field experiment; $(\mathbf{B}(\mathbf{a}, \mathbf{b}))$ Available $\mathrm{N}$, Olsen-P concentration of pot experiment. Capital letters on the column indicate the significant differences among three treatments. Lower case letters on the column indicate significant differences between two species. 


\subsection{Horizontal Variations in Soil Properties}

An increasing trend in soil $\mathrm{pH}$ was found in the horizontal direction from suaeda to maize under non-barrier treatment conditions (Figure 6a), but the $\mathrm{pH}$ value was lower, and the EC was higher at the interface near the nylon barrier (Figure 6b). An increasing trend in available $\mathrm{N}$ developed from suaeda to maize in the nylon-barrier treatments (Figure 6c). As a whole, the Olsen-P in the nylon-barrier treatment was significantly greater than in the non-barrier and plastic-barrier treatments (Figure 6d). Higher available N, Olsen-P levels were found at the interface near the nylon barrier, which also confirmed the possibility of synergy in the non-barrier treatment through the physiological root-dialogue process (Figure 6c,d).
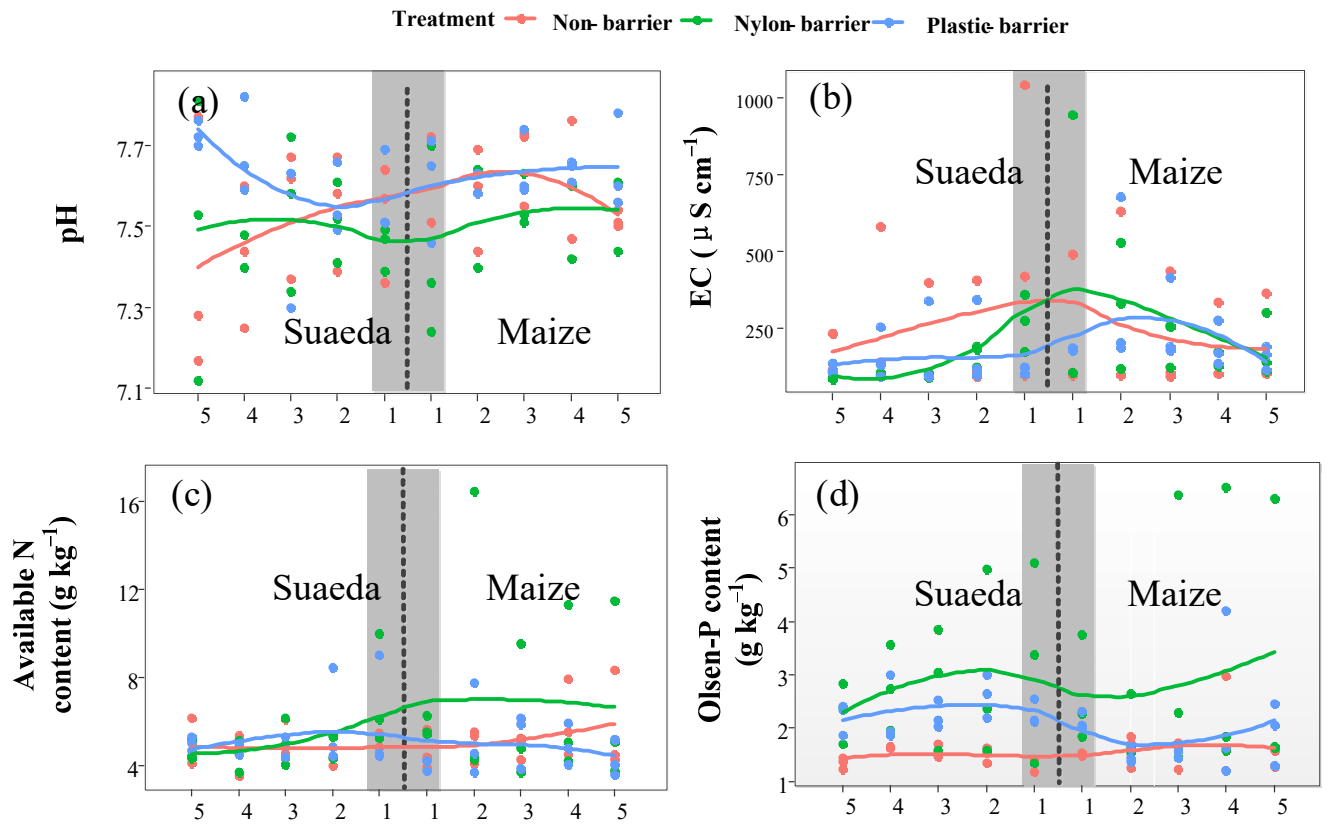

The distance to middle position $(\mathrm{cm})$

The distance to middle position $(\mathrm{cm})$

Figure 6. Variations in soil properties in the different treatments: (a) $\mathrm{pH}$; (b) EC; and (c) available $\mathrm{N}$ content; (d) Olsen-P content of the soil from the middle positions. Dotted black lines and gray shadowing represent the middle positions and the interfaces of the two species, respectively, in the different treatments.

\section{Discussion}

\subsection{The Effects of Intercropping Systems on Biomass}

The promotion of non-halophyte growth was not found in the suaeda/maize intercropping systems, which was inconsistent with the results of previous studies [31,32]. In this study, the non-barrier treated maize biomass was lower than that during the plastic-barrier treatment (Figure 2). Root interaction of two species may have restrained each other's growth in the intercropping systems. Roots of the halophyte have their own adaptive strategy-related responses to saline soil, and physiological responses to the nylon barrier may also exist. A greater salt content near suaeda roots influences maize belowground growth and suppresses the shoot biomass [33]. In addition, inhibitory effects during the intercropping are greatly affected by the planting distance and density, as well as the plant species [34].

\subsection{The Soil Salt's Spatial Variations in The Intercropping Systems}

The study was conducted to determine whether salt migrated from non-halophytes to halophytes in the intercropping systems. The salt level variation in the horizontal direction was not significant in the non-barrier and nylon-barrier treatments, but the salt content was higher at the $20 \mathrm{~cm}$ soil depth on the suaeda side compared to that on the maize side 
(Figure $4 \mathrm{~A}(\mathrm{~b})$ ). This suggests that suaeda has an important ability to gather salt to improve the saline soil. Salt-tolerance has evolved in a variety of vegetative types over long periods, during which non-halophytes might have lost their genetic variation and developed special traits related to high salt-tolerance, such as in crop plants $[1,35,36]$. Some glycophytes, such as maize and wheat, also tend to remove $\mathrm{Na}^{+}$from roots [37]. Suaeda appears to gather and uptake salt into the root zone $[9,38]$, which might reduce the salt injury level and improves the saline-related root environment for maize. This would be explained by the results in the pot experiments that the $\mathrm{Na}^{+}$content displayed higher on the suaeda sides (Figure $4 \mathrm{~B}(\mathrm{~b})$ ). This indicates that the intercropping was more beneficial to the absorption of salt and $\mathrm{Na}^{+}$by suaeda (Figure 7). In addition, it suggests that $\mathrm{Na}^{+}$is an essential factor for suaeda growth and metabolism during the life cycle. However, though the decrement in salt content was displayed, the maize growth was obviously inhibited in the non-barrier treatment, which might have been caused by interspecific competition (Figure 5). Ai et al. discovered that the intercropping disadvantage of jujube was due to niche invasion of cotton, which increased the competition for water [39].

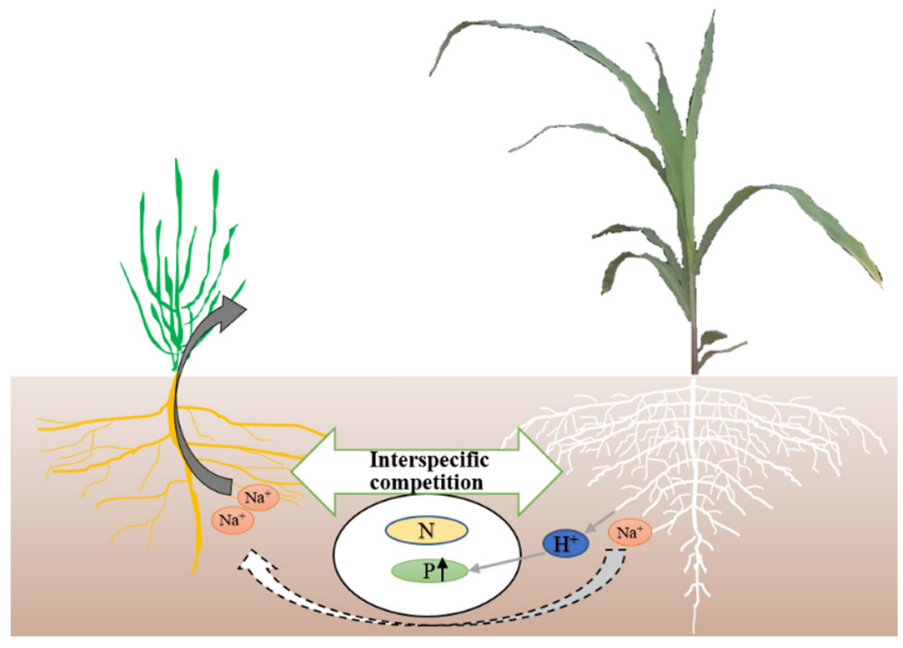

Figure 7. The potential mechanism in the suaeda/maize intercropping systems. Maize's excretion decreases soil $\mathrm{pH}$ to activate more Olsen-P, but it facilitates the $\mathrm{Na}^{+}$shift to the suaeda root zone and interspecific competition for nutrients.

\subsection{Soil Nutrients' Variations in The Suaeda/Maize Intercropping Systems}

The variations in the available $\mathrm{N}$ were obvious among the three intercropping systems. The soil available $\mathrm{N}$ was lower in the non-barrier treatment than that in the plastic treatment, which suggests that suaeda/maize intercropping facilitated interspecific competition to a certain content. Root interactions in an intercropping system may improve resource acquisition and adaptation to nutrient constraints [40,41]. For instance, the disadvantage of maize/barley intercropping was mainly due to the increased interspecific competition for $\mathrm{N}, \mathrm{P}$, and $\mathrm{K}$ between the two plants [42].

However, the competition of soil nutrients between maize and suaeda might be reflected in nitrogen, but not phosphorus. The trends in the soil Olsen-P in the intercropping system were not similar to those of the available N. The soil Olsen-P levels in the non-barrier treatment were higher than in the plastic-barrier treatment (Figure 5), which indicates that $P$ release and absorption were accelerated by root interactions in the suaeda/maize intercropping systems. The significantly higher Olsen-P levels in these systems indicates that intercropping may increase the available nutrient levels, but these results are not consistent with those of previous studies [43-45]. The higher P level on the suaeda side of the nylon barrier, compared with the maize side, may be attributed to maize excretions that acidize the salt. The prominent impact of $\mathrm{pH}$ on soil Olsen-P in the rhizosphere has been demonstrated previously [46]. It could be illustrated that a high nutrient availability was 
displayed at the interface near the nylon barrier, and this was coincident with the low $\mathrm{pH}$ value (Figure 6). This suggested that suaeda/maize intercropping shifted nutrients and ions between the inter-species roots, as reported in previous researches $[14,31,47,48]$. In this study, though we observed a negative effect on maize growth, which was probably due to the nitrogen competition, the issues regarding the role that the root excretions played, and how the excretion-microorganism-soil properties related in this system, were unclear, which should be explored to deeply figure out the mechanism of halophyte/non-halophyte intercropping in subsequent studies.

\title{
5. Conclusions
}

From the experimental data, it can be shown that there is an obvious interspecific ecological competition between suaeda and maize. The decrements in salt and $\mathrm{Na}^{+}$content in the non-barrier treatment suggest that the intercropping plays a positive effect on salt absorption. Comparing the experimental results of nylon barrier treatment with other treatments, it can be shown that the roots of suaeda and maize interact through the exchange of soluble substances. This study on suaeda/maize intercropping may provide new insights into the amelioration of saline soil. Whether it is possible to change the planting pattern (row spacing, fertilization method, etc.) of maize/suaeda or crop selection to address the intercropping disadvantage of maize is a focus of further research.

\begin{abstract}
Author Contributions: Conceptualization, S.W., W.M. and C.T.; methodology, S.W., Z.Z. and W.M.; software, S.W. and S.G.; validation, Z.Z. and C.T.; formal analysis, S.W.; investigation, S.W., S.G. and K.Z.; writing — original draft preparation, S.W.; writing—review and editing, S.W., W.M. and C.T.; visualization, S.W. and S.G.; supervision, Z.Z. and C.T. All authors have read and agreed to the published version of the manuscript.
\end{abstract}

Funding: This study was supported by the National Natural Science Foundation of China (Grant No. U1803233), Joint Regulation Technology of Multi-scale Water Fertilizer Salt in High-Efficiency Water-Saving Irrigation Area (Grant No. 2020A01003-3), Xinjiang Water Resources and Hydropower Planning and Design Administration Bureau (Grant No. SQ20200528151870).

Institutional Review Board Statement: Not applicable.

Informed Consent Statement: Not applicable.

Data Availability Statement: The data will be provided upon request by the corresponding author.

Conflicts of Interest: The authors declare no conflict of interest.

\section{References}

1. Bennett, T.H.; Flowers, T.J.; Bromham, L. Repeated evolution of salt-tolerance in grasses. Biol. Lett. 2013, 9, 0029. [CrossRef]

2. Shabala, S.; Bose, J.; Hedrich, R. Salt bladders: Do they matter? Trends Plant Sci. 2014, 19, 687-691. [CrossRef] [PubMed]

3. Yuan, F.; Leng, B.Y.; Wang, B.S. Progress in studying salt secretion from the salt glands in recretohalophytes: How do plants secrete salt? Front. Plant Sci. 2016, 7, 977. [CrossRef] [PubMed]

4. Zheng, J.; Suhono, G.B.F.; Li, Y.; Jiang, M.Y.; Chen, Y.; Siddique, K.H.M. Salt-tolerance in castor bean (Ricinus communis L.) is associated with thicker roots and better tissue $\mathrm{K}^{+} / \mathrm{Na}^{+}$Distribution. Agriculture 2021, 11, 821. [CrossRef]

5. Chaudhary, D.R.; Kim, J.; Kang, H. Influences of different halophyte vegetation on soil microbial community at Temperate Salt Marsh. Microb. Ecol. 2018, 75, 729-738. [CrossRef]

6. Song, J.; Feng, G.; Tian, C.Y.; Zhang, F.S. Strategies for adaptation of Suaeda physophora, Haloxylon ammodendron and Haloxylon persicum to a saline environment during seed-germination stage. Ann. Bot. 2005, 96, 399-405. [CrossRef] [PubMed]

7. Munns, R.; Greenway, H.; Kirst, G.O. Halotolerant eukaryotes. In Encyclopedia of Plant Physiology; Lange, O.L., Nobel, P.S., Osmond, C.B., Ziegler, H., Eds.; Springer: Berlin, Germany, 1983; Volume 12C, pp. 59-135.

8. Matsushita, N.; Matoh, I. Characterization of $\mathrm{Na}^{\wedge}$ exclusion mechanisms of salt-tolerant reed plants in comparison with saltsensitive rice plants. Physiol. Plant. 1991, 83, 170-176. [CrossRef]

9. Byrt, C.S.; Xu, B.; Krishnan, M.; Lightfoot, D.J.; Athman, A.; Jacobs, A.K.; Watson-Haigh, N.S.; Plett, D.; Munns, R.; Tester, M. The $\mathrm{Na}^{+}$transporter, TaHKT1;5-D, limits shoot $\mathrm{Na}^{+}$accumulation in bread wheat. Plant J. 2014, 80, 516-526. [CrossRef] [PubMed]

10. Wang, L.; Wang, X.; Jiang, L.; Zhang, K.; Tanveer, M.; Tian, C.Y.; Zhao, Z.Y. Reclamation of saline soil by planting annual euhalophyte Suaeda salsa with drip irrigation: A three-year field experiment in arid northwestern China. Ecol. Eng. 2021, 159, 106090. [CrossRef] 
11. Etesami, H.; Beattie, G.A. Mining halophytes for plant growth-promoting halotolerant bacteria to enhance the salinity tolerance of non-halophytic crops. Front. Microbiol. 2018, 9, 148. [CrossRef]

12. Shultana, R.; Kee Zuan, A.T.; Yusop, M.R.; Saud, H.M. Characterization of salt-tolerant plant growth-promoting rhizobacteria and the effect on growth and yield of saline-affected rice. PLoS ONE 2020, 15, e0238537. [CrossRef] [PubMed]

13. Li, L.; Sun, J.H.; Zhang, F.S.; Li, X.L.; Yang, S.C.; Rengel, Z. Wheat/maize or wheat/soybean strip intercropping I. Yield advantage and interspecific interactions on nutrients. Field Crops Res. 2001, 71, 123-137. [CrossRef]

14. Li, L.; Zhang, F.S.; Li, X.L.; Christie, P.; Sun, J.H.; Yang, S.C.; Tang, C.X. Interspecific facilitation of nutrient uptake by intercropped maize and faba bean. Nutr. Cycl. Agroecosyst. 2003, 65, 61-71. [CrossRef]

15. Bi, Y.X.; Zhou, P.; Li, S.J.; Wei, Y.Q.; Xiong, X.; Shi, Y.H.; Liu, N.; Zhang, Y.J. Interspecific interactions contribute to higher forage yield and are affected by phosphorus application in a fully-mixed perennial legume and grass intercropping system. Field Crops Res. 2019, 244, 107636. [CrossRef]

16. Salgado, G.C.; Ambrosano, E.J.; Rossi, F.; Otsuk, I.P.; Ambrosano, G.M.B.; Santana, C.A.; Muraoka, T.; Trivelin, P.C.O. Biological N fixation and $\mathrm{N}$ transfer in an intercropping system between legumes and organic cherry tomatoes in succession to green corn. Agriculture 2021, 11, 690. [CrossRef]

17. Vandermeer, J.H. The Ecology of Intercropping; Cambridge University Press: Cambridge, UK, 1989.

18. Lv, J.X.; Dong, Y.; Dong, K.; Zhao, Q.; Yang, Z.X.; Chen, L. Intercropping with wheat suppressed Fusarium wilt in faba bean and modulated the composition of root exudates. Plant Soil 2020, 448, 153-164. [CrossRef]

19. Tian, J.; Tang, M.; Xu, X.; Luo, S.; Condron, L.M.; Lambers, H.; Cai, K.; Wang, J. Soybean (Glycine max (L.) Merrill) intercropping with reduced nitrogen input influences rhizosphere phosphorus dynamics and phosphorus acquisition of sugarcane (Saccharum officinarum). Biol. Fertil. Soils 2020, 56, 1063-1075. [CrossRef]

20. Sashidhar, B.; Podile, A.R. Mineral phosphate solubilization by rhizosphere bacteria and scope for manipulation of the direct oxidation pathway involving glucose dehydrogenase. J. Appl. Microbiol. 2010, 109, 1-12. [CrossRef]

21. Lamers, L.P.; van Diggelen, J.M.; Op den Camp, H.J.; Visser, E.J.; Lucassen, E.C.; Vile, M.A.; Jetten, M.S.; Smolders, A.J.; Roelofs, J.G. Microbial transformations of nitrogen, sulfur, and iron dictate vegetation composition in wetlands: A review. Front. Microbiol. 2012, 3, 156. [CrossRef]

22. Liang, J.; Shi, W.J. Cotton/halophytes intercropping decreases salt accumulation and improves soil physicochemical properties and crop productivity in saline-alkali soils under mulched drip irrigation: A three-year field experiment. Field Crops Res. 2021, 262, 108027. [CrossRef]

23. Song, J.; Wang, B. Using euhalophytes to understand salt tolerance and to develop saline agriculture: Suaeda salsa as a promising model. Ann. Bot. 2014, 115, 541-553. [CrossRef]

24. Barhoumi, Z.; Trabelsi, N.; Atia, A.; Djebali, W.; Chaibi, W.; Abdelly, C.; Smaoui, A. Salt stress response in the halophyte Limoniastrum guyonianum Boiss. Flora 2015, 217, 1-9. [CrossRef]

25. Zhao, S.; Liu, J.J.; Banerjee, S.; Zhou, N.; Zhao, Z.Y.; Zhang, K.; Tian, C.Y. Soil pH is equally important as salinity in shaping bacterial communities in saline soils under halophytic vegetation. Sci. Rep. 2018, 8, 4550. [CrossRef]

26. Guo, J.R.; Du, M.; Lu, C.X.; Wang, B.S. NaCl improves reproduction by enhancing starch accumulation in the ovules of the euhalophyte Suaeda salsa. BMC Plant Biol. 2020, 20, 262. [CrossRef] [PubMed]

27. Wang, Y.F.; Qin, Y.Z.; Chai, Q.; Feng, F.X.; Zhao, C.; Yu, A.Z. Interspecies interactions in relation to root distribution across the rooting profile in wheat-maize intercropping under different plant densities. Front. Plant Sci. 2018, 9, 483. [CrossRef] [PubMed]

28. Bao, S.D. Soil and Agricultural Chemistry Analysis; China Agriculture Press: Beijing, China, 2000.

29. Shen, J.B.; Mao, D.R. Research Methods of Plant Nutrition; China Agricultural University Press: Beijing, China, 2011.

30. Wang, Q.T.; Xiao, J.; Ding, J.X.; Zou, T.T.; Zhang, Z.L.; Liu, Q.; Yin, H.J. Differences in root exudate inputs and rhizosphere effects on soil $\mathrm{N}$ transformation between deciduous and evergreen trees. Plant Soil 2021, 458, 277-289. [CrossRef]

31. Latati, M.; Aouiche, A.; Tellah, S.; Laribi, A.; Benlahrech, S.; Kaci, G.; Ouarem, F.; Ounane, S.M. Intercropping maize and common bean enhances microbial carbon and nitrogen availability in low phosphorus soil under Mediterranean conditions. Eur. J. Soil Biol. 2017, 80, 9-18. [CrossRef]

32. Ling, Q.; Zhao, X.N.; Wu, P.T.; Gao, X.D.; Sun, W.H. Effect of the fodder species canola (Brassica napus L.) and daylily (Hemerocallis fulva L.) on soil physical properties and soil water content in a rainfed orchard on the semiarid Loess Plateau, China. Plant Soil 2019, 453, 209-228. [CrossRef]

33. Radhakrishnan, R.; Baek, K.H. Physiological and biochemical perspectives of non-salt tolerant plants during bacterial interaction against soil salinity. Plant Physiol. Biochem. 2017, 116, 116-126. [CrossRef]

34. Song, D.; Tariq, A.; Pan, K.; Khan, S.U.; Saleh, T.A.; Gong, S.; Zhang, A.; Wu, X. Influence of planting distance and density on the yield and photosynthetic traits of sweet potato (Ipomoea balatas L.) under an intercropping system with walnut (Juglans regia) saplings. Soil Tillage Res. 2020, 196, 104484. [CrossRef]

35. McDonald, G.K.; Taylor, J.D.; Verbyla, A.; Kuchel, H. Assessing the importance of subsoil constraints to yield of wheat and its implications for yield improvement. Crop Pasture Sci. 2013, 63, 1043-1065. [CrossRef]

36. Bian, A.N.; Lin, M.; Wang, W.Q.; Bin, W.S. Effects of root salt stress on growth and allocation of mineral elements in halophyte and glycophyte seedlings. J. Trop. Subtrop. Bot. 2015, 23, 405-412.

37. Ilangumaran, G.; Smith, D.L. Plant growth promoting rhizobacteria in amelioration of salinity stress: A systems biology perspective. Front Plant Sci. 2017, 8, 1768. [CrossRef] 
38. Alharby, H.F.; Colmer, T.D.; Barrett-Lennard, E.G. Salinization of the soil solution decreases the further accumulation of salt in the root zone of the halophyte Atriplex nummulariaLindl. growing above shallow saline groundwater. Plant Cell Environ. 2018, 41, 99-110. [CrossRef] [PubMed]

39. Ai, P.R.; Ma, Y.J.; Hai, Y. Jujube is at a competitiveness disadvantage to cotton in intercropped system. Agron. J. 2021, 113, 3475-3488. [CrossRef]

40. Nafi, E.; Webber, H.; Danso, I.; Naab, J.B.; Frei, M.; Gaiser, T. Soil tillage, residue management and site interactions affecting nitrogen use efficiency in maize and cotton in the Sudan Savanna of Africa. Field Crops Res. 2019, 244, 107629. [CrossRef]

41. Li, L.; Sun, J.; Zhang, F.S.; Guo, T.; Bao, X.; Smith, F.A.; Smith, S.E. Root distribution and interactions between intercropped species. Oecologia 2005, 147, 280-290. [CrossRef]

42. Liu, G.C.; Li, L.; Huang, G.B.; Sun, J.H.; Guo, T.W.; Zhang, F.S. Intercropping advantage and contribution of above-ground and below-ground interactions in the barley-maize intercropping. Sci. Agric. Sin. 2005, 38, 1787-1795.

43. Hinsinger, P.; Betencourt, E.; Bernard, L.; Brauman, A.; Plassard, C.; Shen, J.B.; Tang, X.Y.; Zhang, F.S. P for two, sharing a scarce resource: Soil phosphorus acquisition in the rhizosphere of intercropped species. Plant Physiol. 2011, 156, 1078-1086. [CrossRef]

44. Wang, Y.L.; Almvik, M.; Clarke, N.; Eich-Greatorex, S.; Ogaard, A.F.; Krogstad, T.; Lambers, H.; Clarke, J.L. Contrasting responses of root morphology and rootexuded organic acids to low phosphorus availability in three important food crops with divergent root traits. AoB Plants 2015, 7, plv097. [CrossRef]

45. Gitari, H.I.; Karanja, N.N.; Gachene, C.K.K.; Kamau, S.; Sharma, K.; Schulte-Geldermann, E. Nitrogen and phosphorous uptake by potato (Solanum tuberosum L.) and their use efficiency under potato-legume intercropping systems. Field Crops Res. 2018, 222, 78-84. [CrossRef]

46. Mai, W.X.; Xue, X.R.; Feng, G.; Yang, R.; Tian, C.Y. Can optimization of phosphorus input lead to high productivity and high phosphorus use efficiency of cotton through maximization of root/mycorrhizal efficiency in phosphorus acquisition? Field Crops Res. 2018, 216, 100-108. [CrossRef]

47. Li, H.G.; Shen, J.B.; Zhang, F.S.; Marschner, P.; Cawthray, G.; Rengel, Z. Phosphorus uptake and rhizosphere properties of intercropped and monocropped maize, faba bean, and white lupin in acidic soil. Biol. Fertil. Soils 2010, 46, 79-91. [CrossRef]

48. Song, Y.N.; Zhang, F.S.; Marschner, P.; Fan, F.L.; Gao, H.M.; Bao, X.G.; Sun, J.H.; Li, L. Effect of intercropping on crop yield and chemical and microbiological properties in rhizosphere of wheat (Triticum aestivum L.), maize (Zea mays L.), and faba bean (Vicia faba L.). Biol. Fertil. Soils 2007, 43, 565-574. [CrossRef] 